\title{
USE OF THE SYSTEMS DATA-FOSSIL AND CRONOS IN STRATIGRAPHIC DATATIONS OF MESO-CENOZOIC ROCKS
}

\author{
GIL-GONZÁLEZ, Santa; RAMÍREZ-HERNÁNDEZ, Robert; MIRANDA-CASTAÑEDA, \\ Luis F. , Universidad de Pinar del Río, Dpto de Geol., Martí No 270., CP 20100, P. del R., \\ Cuba.
}

Due to great information volume that is necesary to analyze in the paleontological and stratigraphical works surges the necsity of creating automated systems capable of carrying out these operations of selection, comparison, discrimination and storage of the information in a fast way and also precise. With the use of these systems facilitate extraordinarily the operations of search in the range charts of the biostratigraphic ages of each studied fossil. With the same one could date samples of ages from the Jurassic to the Recent.

Those systems a part from have great importance as educational material they are converted in fact in a tool of work for the researchers.

The data base contains the ranges of the following taxa: planktonic foraminifera, larger foraminifera, calpionellids and incertae sedis and rudists, as well as biostratigraphic zonations.

The essence of both systems is, starting from the selection in the ranges of the present fossils in the sample, to get as resulted the age of the redepositions, if these exists.

Between the DATAFOSSIL and the CRONOs exists differences about their potentialy. The first, with an utility educational primarily, it only permit the datation of samples not from lithostratigraphic units, it neither could carry out correlations between different biostratigraphic zonations, for which one must utilize the only one the system offers.

In the case of the CRONOs, this allows starting from a group of samples previous dated, subsequently filed and assembled by packages or sequences (lower, middle, upper), dating lithostratigraphic units and choose, of the six contained biozonations in the data base, the one wich is needed for the utilize.

In order to demostrate their effectiviness it was employed the system in the determination of the sample age of the Upper Cretaceous Maastrichtian Cacarajicara Formation (Western Cuba), as well as of the different packages of the unit, whose result has coincided with those obtained by the specialists. There by it shows the effectiviness of the use of the systems in the determination of the paleontological age of samples and lithostratigraphic units, beside make possible the equivalence between several biozonations, also permits the storage and rapid and sure handling of the biostratigraphic informations in great measurement. 